\title{
Review: Sistem Penghantaran Obat Tertarget Epidermal Growth Factor Receptor pada Kanker Payudara
}

\author{
Cecep Suhandi ${ }^{*}, 1$ \\ ${ }^{1}$ Program Studi Profesi Apoteker, Fakultas Farmasi, Universitas Padjadjaran, \\ Jln. Raya Bandung Sumedang km 21 Jatinangor, Sumedang 45363, Indonesia \\ *E-mail: cecep17001@mail.unpad.ac.id \\ (Submit 27/7/2021, Revisi 10/8/2021, Diterima 19/8/2021, Terbit 3/11/2021)
}

\begin{abstract}
Abstrak
Kanker payudara menjadi salah satu penyebab utama kematian akibat kanker pada populasi wanita di dunia. Tingginya kematian yang terjadi berkorelasi dengan rendahnya efektivitas terapi yang diberikan. Melalui sistem penghantaran obat tertarget pada pengobatan kanker payudara menjadi alternatif baru dalam upaya peningkatan efektivitas terapi. Tinjauan sistematis ini bertujuan untuk menelusuri dan mengumpulkan berbagai data yang memuat potensi terkait perkembangan sistem penghantaran obat tertarget EGFR pada pengobatan kanker payudara. Penelusuran data dilakukan menggunakan kata kunci "((Breast Cancer) AND (Targeted Drug Delivery) AND (Epidermal Growth Factor Receptor OR EGFR)) NOT Review" pada basis data Scopus, ScienceDirect, dan PubMed Central. Berdasarkan telaah artikel, diketahui bahwa sistem penghantaran tertarget EGFR pada kanker payudara saat ini dikembangkan dalam bentuk konjugat antibodi-obat, nanopartikel aptamer-protamine-siRNA (APR), konjugat affibodi-hibrid DNA, antibodi biparatopik-bispesifik, konjugat sel T-Designed Ankyrin Repeat Proteins (DAR-Pins), konjugat multikomponen dalam bentuk dendrimer PAMAM, dan chimera bivalen aptamer-siRNA. Selain itu, target spesifik yang banyak digunakan dalam metode terkini meliputi EGFR natural, HER2, HER3, asam folat, serta gen ErbB3. Perkembangan ini menunjukkan besarnya potensi terapi berbasis penghantaran tertarget EGFR dalam pengobatan kanker payudara.
\end{abstract}

Kata kunci: EGFR, kanker payudara, sistem penghantaran obat tertarget

\section{Pendahuluan}

Kanker payudara merupakan jenis kanker yang umum menyerang wanita serta menjadi penyebab kematian utama akibat kanker. Berdasarkan data yang dihimpun oleh Badan Kesehatan Dunia (World Health Organization), prevalensi kanker payudara secara global menunjukkan bahwa sekitar 2,1 juta wanita tercatat mengidap kanker payudara setiap tahunnya. Selain itu, kanker payudara juga menunjukkan angka kematian yang tinggi dimana pada tahun 2018 sekitar 15\% dari penyandang kanker payudara di dunia mengalami kematian (WHO, 2020a). Penyebab dari tingginya angka kematian akibat kanker payudara diprediksi terjadi akibat lambatnya diagnosis dan kurangnya penanganan yang efektif terhadap pasien kanker payudara(1,2) 
Metode pengobatan kanker payudara saat ini belum mampu memberikan dampak yang signifikan dalam upaya remisi pasien. Pengobatan terkini kanker payudara masih mengandalkan berbagai metode, meliputi tindakan operatif, terapi radiasi, dan kemoterapi $(3,4)$. Namun demikian, penggunaan metode ini masih menunjukkan berbagai kekurangan, baik dalam hal aspek efikasi maupun keamanan. Salah satu kondisi penting pada pasien dimana prognosis pasien cenderung buruk akibat metode pengobatannya yang masih belum efektif adalah pada pasien dengan kondisi kanker bermetastasis. Pada kondisi ini, sel kanker mengekspresikan secara berlebih suatu reseptor permukaan berupa epidermal growth factor receptor (EGFR). EGFR pada sistem homeostasis manusia terdiri dari 4 famili yang merupakan suatu glikoprotein transmembran yang mengandung domain pengikat ligan ekstraseluler dan domain reseptor tirosin kinase intraseluler. Keempat famili EGFR tersebut di antaranya meliputi HER1/erbB1, HER2/neu atau yang kini lebih dikenal sebagai HER2, HER3/erbB3, dan HER4/erbB4 dimana sekitar 10-30\% merupakan reseptor pada famili HER2 (Human Epidermal Growth Factor Receptor 2)(5,6). HER-2 merupakan reseptor EGFR yang digunakan sebagai dasar diagnosis pada kanker payudara serta menjadi satu-satunya famili EGFR yang tidak memiliki domain pengikat ligan ekstraseluler sehingga penargetan pada HER2 berbasis pada antibodi monoklonal( ${ }^{(6)}$.

Salah satu kemoterapi yang wajib diberikan kepada pasien dengan kondisi ini adalah anti-HER2. Anti-HER2 yang tersedia saat ini belum mampu memberikan efektivitas yang diharapkan terhadap pasien. Selain itu, trastuzumab sebagai agen anti-HER2 yang banyak digunakan juga masih menunjukkan profil keamanan yang kurang baik dimana penggunaannya berisiko menyebabkan kardiotoksisitas pada penggunaan dosis yang terlalu tinggi ${ }^{(7)}$. Bagaikan sebuah paradigma, penggunaan trastuzumab dalam dosis rendah juga menunjukkan resiko resistensi akibat toleransi dari penggunaan trastuzumab yang kurang efektif(8). Hal ini menunjukkan bahwa pengembangan dalam metode pengobatan pada kanker payudara dengan overekspresi EGFR perlu dilakukan.

Salah satu alternatif yang dapat menjadi solusi atas permasalahan ini adalah kemajuan di bidang sistem baru penghantaran obat. Berbagai penelitian telah banyak dilakukan dengan upaya melakukan dekorasi pada suatu agen sitotoksik yang akan dihantarkan dengan ligan penarget spesifik. Sistem ini banyak dikenal sebagai sistem penghantaran obat tertarget. Sebuah studi menunjukkan bahwa melalui proses penghantaran obat tertarget ini dapat meningkatkan spesifisitas serta efektivitas dari suatu obat ${ }^{(9)}$. Dengan demikian, pengetahuan serta data mengenai perkembangan sistem penghantaran obat tertarget (dalam hal ini terhadap EGFR sebagai marker spesifik pada kanker payudara) sangat diperlukan untuk meningkatkan percepatan penelitian, baik dalam hal penemuan maupun pengembangan sediaannya hingga diperoleh obat resmi (approved and marketed drug). Tinjauan sistematis ini bertujuan untuk mengumpulkan data serta menelusuri potensi terkait perkembangan sistem penghantaran obat tertarget EGFR pada pengobatan kanker payudara. Melalui tinjauan sistematis ini diharapkan dapat menjadi panduan bagi para peneliti dalam menentukan serta mengembangkan sistem penghantaran obat tertarget EGFR pada kanker payudara yang efektif dan efisien. 


\section{Metode}

Tinjauan pustaka sistematis ini mengikuti kaidah Preferred Reporting Items for Systematic Review and Meta-Analyzes (PRISMA) untuk meningkatkan kredibilitas dari penelitian ini. Adapun pengumpulan sumber literatur diperoleh melalui pencarian artikel pada tiga basis data, yakni Scopus, ScienceDirect, dan PubMed Central menggunakan kata kunci "((Breast Cancer) AND (Targeted Drug Delivery) AND (Epidermal Growth Factor OR EGFR)) NOT Review" pada rentang waktu 10 tahun terakhir. Sebanyak 3.864 artikel diperoleh dan dilakukan eliminasi duplikat menggunakan EndNote reference manager menghasilkan sebanyak 3.847 artikel.

Berdasarkan kata kunci di atas, artikel yang diperoleh kemudian dipilih berdasarkan kriteria inklusi sebagaimana berikut:

1. Objek pada penelitian merupakan pengembangan sediaan tertarget pada kelainan kanker payudara

2. Target obat pada penelitian yang dilakukan adalah epidermal growth factor receptor (EGFR)

Pada tahapan ini, diperoleh sebanyak 31 artikel yang memenuhi kriteria inklusi dan layak untuk dilakukan analisa lebih lanjut.

Pada tahap selanjutnya, dilakukan telaah lebih lanjut mengenai hasil penelitian obat dalam bentuk sistem penghantaran tertarget terhadap EGFR. Artikel yang sudah terkumpul kemudian dipilih kembali berdasarkan ketersediaan data yang termuat meliputi jenis sistem penghantaran, zat aktif, ligan penarget, reseptor target, serta efektivitas dari sediaan yang diuji. Pada tahap ini, 11 artikel dapat dianalisis lebih lanjut untuk menemukan sediaan tertarget EGFR potensial dalam pengobatan kanker payudara.

\section{Hasil}

Berdasarkan hasil penelusuran menggunakan kata kunci sebagaimana telah disebutkan dalam metode, diperoleh bagan hasil penelusuran artikel sebagaimana terlampir pada Gambar 1. 

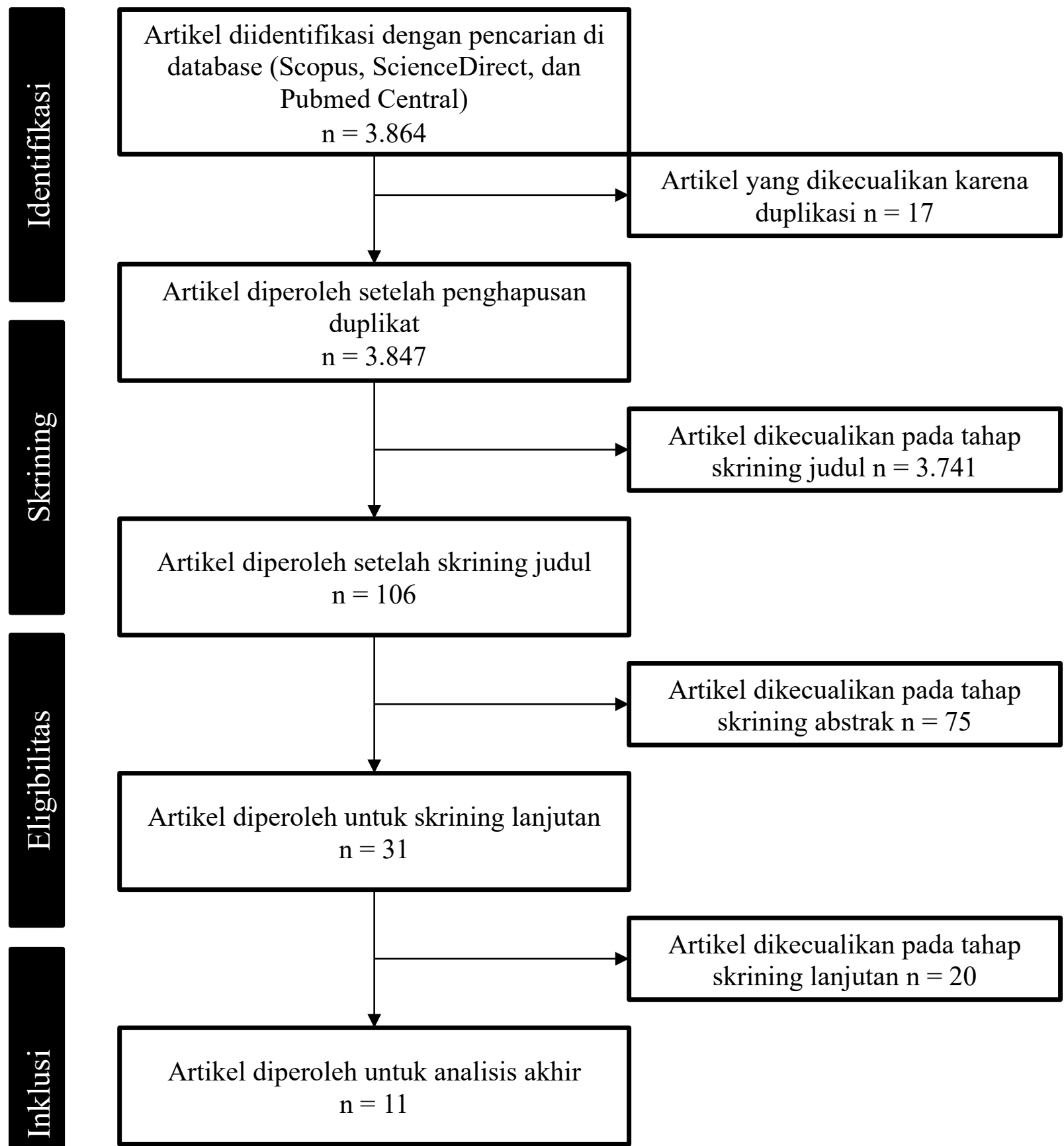

Gambar 1. Skema pemilihan artikel berdasarkan panduan tinjauan literatur sistematis PRISMA menggunakan kata kunci "((Breast Cancer) AND (Targeted Drug Delivery) AND (Epidermal Growth Factor OR EGFR)) NOT Review". Hasil penelitian menunjukkan bahwa 11 artikel ditinjau dari 3.864 artikel yang diperoleh.

Dari sejumlah 11 artikel yang dapat dianalisa lebih lanjut, diperoleh hasil tinjauan mengenai potensi sediaan tertarget EGFR pada penanganan kanker payudara sebagaimana terlampir pada Tabel 1. 
Tabel 1. Sistem penghantaran obat tertarget epidermal growth factor receptor (EGFR) dalam pengobatan kanker payudara

\begin{tabular}{|c|c|c|c|c|c|c|}
\hline No. & $\begin{array}{c}\text { Sistem } \\
\text { Penghantaran }\end{array}$ & Zat Aktif & $\begin{array}{c}\text { Ligan } \\
\text { Penarget }\end{array}$ & $\begin{array}{l}\text { Reseptor } \\
\text { Target }\end{array}$ & Efektivitas & Referensi \\
\hline \multirow[t]{5}{*}{1.} & $\begin{array}{l}\text { Konjugat antibodi- } \\
\text { obat }\end{array}$ & Mertansin & $\begin{array}{l}\text { Antibodi } \\
\text { monoklonal } \\
\text { anti-EGFR }\end{array}$ & $\begin{array}{l}\text { EGFR } \\
\text { natural }\end{array}$ & 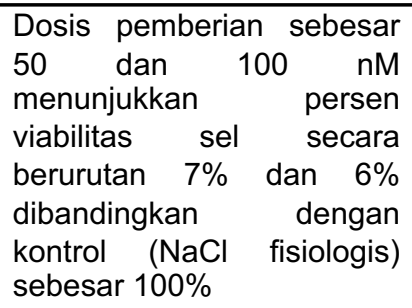 & (10) \\
\hline & & $\begin{array}{ll}\text { DXd } & \text { (turunan } \\
\text { eksatekan) } & \end{array}$ & $\begin{array}{l}\text { Trastuzum } \\
\text { ab-like } \\
\text { antibody }\end{array}$ & HER2 & $\begin{array}{l}\text { Sediaan kombinasi } \\
\text { (DS8201a) menunjukkan } \\
\text { viabilitas sel yang rendah } \\
\text { pada uji in vitro terhadap } \\
\text { sel KPL-4, namun masih } \\
\text { lebih tinggi dibanding } \\
\text { dengan T-DM1. Secara in } \\
\text { vivo, sediaan ini efektif, } \\
\text { baik terhadap sel NCl-N87 } \\
\text { maupun MDA-MB-468-Luc }\end{array}$ & (11) \\
\hline & & Doksorubisin & $\begin{array}{l}\text { Asam Folat } \\
\text { dan } \\
\text { Trastuzum } \\
\text { ab }\end{array}$ & $\begin{array}{l}\text { HER2 } \\
\text { dan } \\
\text { reseptor } \\
\text { asam } \\
\text { folat }\end{array}$ & $\begin{array}{l}\text { Studi in vivo menunjukkan } \\
\text { bahwa konjugat mampu } \\
\text { menurunkan regresi tumor } \\
\text { sebesar } 91 \% \text { dibandingkan } \\
\text { dengan pemberian } \\
\text { doksorubisin saja }\end{array}$ & (12) \\
\hline & & $\begin{array}{l}\text { Emtansin (DM1) dan } \\
\text { Near-infrared } \\
\text { photochemoimmuno- } \\
\text { therapy (NIR-PIT) } \\
\text { IR700 }\end{array}$ & $\begin{array}{l}\text { Trastuzum } \\
\text { ab }\end{array}$ & HER2 & $\begin{array}{l}\text { Kombinasi DM1 dan NIR- } \\
\text { PIT terkonjugasi } \\
\text { trastuzumab menunjukkan } \\
\text { penurunan yang signifikan } \\
\text { pada ukuran tumor kecil } \\
\text { maupun besar }\end{array}$ & (13) \\
\hline & & Deruxtecan & Patritumab & HER3 & $\begin{array}{l}\text { Pemberian dosis tunggal } \\
\text { memberikan efektivitas } \\
\text { yang baik pada sel kanker } \\
\text { dengan HR+/HER2- }\end{array}$ & (14) \\
\hline 2. & $\begin{array}{l}\text { Nanopartikel } \\
\text { aptamer- } \\
\text { protamine-siRNA } \\
\text { (APR) }\end{array}$ & siRNA & $\begin{array}{l}\text { Aptamer } \\
\text { ErbB3 }\end{array}$ & ErbB3 & $\begin{array}{l}\text { Penggunaan kombinasi } \\
\text { aptamer ErbB3 dengan } \\
\text { siRNA memberikan efek } \\
\text { silencing ekspresi gen } \\
\text { target secara spesifik pada } \\
\text { sel dengan over-ekspresi } \\
\text { ErbB3 }\end{array}$ & (15) \\
\hline 3. & $\begin{array}{l}\text { Konjugat affibodi- } \\
\text { hibrid DNA }\end{array}$ & $\begin{array}{l}\text { 5-fuorodeoxyuridine } \\
\text { dan doksorubisin via } \\
\text { nanopartikel emas }\end{array}$ & $\begin{array}{l}\text { Sekuens } \\
\text { affibodi } \\
\text { Z }_{\text {hcHER2:342 }}\end{array}$ & HER2 & $\begin{array}{l}\text { Penghantaran secara hibrid } \\
\text { tertarget antara dua } \\
\text { senyawa aktif memberikan } \\
\text { efek inhibisi dan sinergistik } \\
\text { yang lebih dibandingkan } \\
\text { dengan pemberian } \\
\text { kombinasi secara terpisah }\end{array}$ & (16) \\
\hline
\end{tabular}




\begin{tabular}{|c|c|c|c|c|c|}
\hline 4. & $\begin{array}{l}\text { Antibodi } \\
\text { biparatopik- } \\
\text { bispesifik }\end{array}$ & $\begin{array}{l}\text { Fragmen Fab anti- } \\
\text { CD3 }\end{array}$ & $\begin{array}{l}\text { Fragmen } \\
\text { paratop } \\
\text { anti-HER2 }\end{array}$ & HER2 & $\begin{array}{l}\text { Kombinasi } \\
\text { bivalen/biparatopik pada } \\
\text { konjugat memberikan } \\
\text { efektivitas lebih baik apabila } \\
\text { dibandingkan dengan } \\
\text { konjugat monovalen }\end{array}$ \\
\hline 5. & $\begin{array}{l}\text { Konjugat Sel T- } \\
\text { Designed Ankyrin } \\
\text { Repeat Proteins } \\
\text { (DAR-Pins) }\end{array}$ & $\begin{array}{l}\text { Chimeric Antigen } \\
\text { Receptor-Engineered } \\
T \text { Cells (CAR-T) }\end{array}$ & $\begin{array}{l}\text { Designed } \\
\text { Ankyrin } \\
\text { Repeat } \\
\text { Proteins } \\
\text { (DAR- } \\
\text { Pins) }\end{array}$ & HER2 & $\begin{array}{l}\text { Kombinasi DAR-Pins pada } \\
\text { CAR-T memberikan efek } \\
\text { sitotoksik lebih besar } \\
\text { dibandingkan dengan } \\
\text { pemberian CAR-T saja }\end{array}$ \\
\hline 6. & $\begin{array}{l}\text { Konjugat } \\
\text { multikomponen } \\
\text { dalam bentuk } \\
\text { dendrimer } \\
\text { PAMAM }\end{array}$ & $\begin{array}{l}\text { Dosetaksel } \\
\text { paklitaksel }\end{array}$ & $\begin{array}{l}\text { Trastuzum } \\
\text { ab }\end{array}$ & HER2 & $\begin{array}{l}\text { Konjugat dendrimer PAMAM } \\
\text { dari doksorubisin maupun } \\
\text { paklitaksel menunjukkan } \\
\text { efektivitas tinggi pada sel } \\
\text { MCF-t HER2+ dan toksisitas } \\
\text { rendah pada sel MCF-7 } \\
\text { HER2- }\end{array}$ \\
\hline 7. & $\begin{array}{l}\text { Chimera bivalen } \\
\text { aptamer-siRNA }\end{array}$ & siRNA EGFR & $\begin{array}{l}\text { Aptamer } \\
\text { HER2 }\end{array}$ & HER2 & $\begin{array}{l}\text { Melalui pemberian bivalen } \\
\text { aptamer-siRNA memberikan } \\
\text { efek supresi, baik pada } \\
\text { HER2 maupun EGFR. } \\
\text { Efektivitas tinggi terjadi } \\
\text { secara spesifik pada sel } \\
\text { dengan ekspresi HER2 }\end{array}$ \\
\hline
\end{tabular}

\section{Pembahasan}

\section{Konjugat Antibodi-Obat}

Konjugat antibodi-obat (KAO) menjadi salah satu inovasi menjanjikan dalam upaya pemberian terapi secara personal. KAO dalam pengobatan kanker dikonstruksikan dengan melakukan tautan silang antara agen obat sitotoksik dengan suatu antibodi monoklonal yang menargetkan antigen yang diekspresikan berlebih dibandingkan dengan ekspresi pada sel normal(21). Melalui dekorasi obat dengan ligan penarget, sediaan sitotoksik dapat memberikan efektivitas yang lebih baik. Selain itu, antibodi yang tercakup pada sistem KAO ini dapat menargetkan senyawa aktif sitotoksik hanya pada sel kanker yang mengekspresikan EGFR secara berlebih. Dengan demikian, hal ini dapat mencegah efek sitotoksik pada sel normal yang dalam kata lain dapat meningkatkan profil spesifisitas yang berimplikasi pada penurunan toksisitas terhadap sel normal(22,24).

Struktur utama dalam pengembangan KAO memerlukan tiga komponen utama, meliputi antibodi, penaut (linker), dan muatan (dalam hal ini agen sitotoksik)(23). Sejauh ini, hanya ada dua KAO yang telah memperoleh lisensi dalam penggunaannya sebagai pilihan terapi pada pengobatan kanker. KAO pertama adalah kombinasi antara trastuzumab dan emtansin (DM1) yang biasa juga disebut sebagai T-DM1. T-DM1 ini merupakan pilihan terapi pada pasien kanker payudara dengan overekspresi HER2 ${ }^{(24,25)}$. Adapun KAO lain yang sudah memperoleh lisensi adalah brentuximab vedotin dalam penggunaannya sebagai agen terapi pada Limfoma Hodgkin dengan over ekspresi CD30(24,26). 
Upaya pengembangan KAO dalam meningkatkan efektivitas dan keamanan terapi pada kanker payudara senantiasa mengalami perkembangan. Salah satunya adalah peningkatan efektivitas terapi dari T-DM1 melalui tautan silang Near-infrared photochemoimmuno-therapy (NIR-PIT) IR700 pada DM1. Melalui konjugasi ini, KAO TDM1 yang sebelumnya hanya berfungsi sebagai agen kemoimunoterapi, juga menunjukkan fungsi sebagai fotoimunoterapi. Dengan kata lain, sediaan kombinasi ini menghasilkan efek fotokemoimunoterapi ${ }^{(13)}$. Penggunaan NIR-PIT IR700 ini merupakan sebuah temuan besar dalam inovasi penemuan metode terapi radiasi non-invasif. Melalui tautan pada T-DM1, maka efek yang diberikan oleh NIR-PIT hanya terjadi secara lokal pada area dimana sel mengekspresikan HER2 secara berlebih(22,27).

Selain itu, strategi peningkatan efektivitas KAO juga dilakukan dengan mengganti agen sitotoksik menggunakan agen yang lebih poten maupun dengan menggunakan antibodi terhadap antigen lain yang lebih spesifik pada kanker payudara. Salah satunya adalah konstruksi KAO menggunakan turunan eksatekan (DXd) dan antibodi sintesis menyerupai trastuzumab menghasilkan KAO baru, yakni DS8201a(11). Agen sitotoksik yang digunakan pada KAO ini memiliki mekanisme kerja berbeda dengan emtansin, yakni sebagai agen inhibitor topoisomerase $I^{(28)}$. Penggunaan antibodi sintesis juga dilakukan sebagai upaya dalam mencari alternatif penggunaan trastuzumab yang dinilai masih belum efektif secara biaya ${ }^{(11)}$.

Strategi lain melalui inovasi pengembangan antibodi penarget yang lebih spesifik juga banyak diterapkan. Salah satunya melalui penambahan agen penarget terhadap reseptor lain, yakni asam folat ${ }^{(12)}$. Hal ini didasarkan pada fakta bahwa sel dengan pertumbuhan abnormal memerlukan asam folat lebih banyak dibandingkan dengan sel normal untuk memenuhi kebutuhannya dalam sintesis molekul DNA(29). Dalam sebuah studi, dualisme penarget ini terbukti meningkatkan efek terapi dibandingkan dengan hanya menggunakan trastuzumab saja sebagai penarget ${ }^{(12)}$. Selain melalui dualisme penarget dengan asam folat, pengubahan pada antigen target juga dilakukan terhadap HER3 dan EGFR ${ }^{(10,14)}$. Pasien dengan ekspresi HER3 dan EGFR diketahui berkorelasi dengan prognosis yang buruk pada diagnosis reseptor hormon negatif(30,31).

Namun demikian, pengembangan sediaan berbasis KAO di masa yang akan datang harus memperhatikan berbagai faktor, meliputi teknologi dalam meningkatkan homogenitas sediaan serta stabilitas ikatan taut silang yang terjadi. Oleh sebab itu, inovasi masih harus terus diperlukan untuk memperoleh antibodi monoklonal yang lebih spesifik, agen sitotoksik yang lebih poten, serta sistem tautan silang yang lebih inovatif ${ }^{(32)}$. 
Nanopartikel Aptamer-Protamine-siRNA (APR)

Nanopartikel Aptamer-protamine-siRNA (APR) merupakan sebuah konstruksi sediaan tertarget menggunakan aptamer sebagai penarget dan siRNA (small interfering RNA) sebagai zat aktif(15). Aptamer sendiri merupakan sebuah konstruksi DNA maupun RNA buatan dalam bentuk untai tunggal yang memiliki afinitas spesifik terhadap gen target tertentu(33). Penggunaan aptamer sebagai penarget memiliki berbagai kelebihan dibandingkan dengan antibodi, di antaranya waktu pembuatan yang lebih singkat, biaya produksi yang lebih murah, variabilitas rendah, mudah dimodifikasi, stabil terhadap perubahan suhu, serta potensi penargetan yang luas pada berbagai target ${ }^{(34)}$. Adapun protamin dalam konstruksi ini digunakan sebagai linker karena memiliki kemampuan dalam mengikat untaian molekul DNA(15).

Zat aktif yang digunakan pada sistem ini, yakni siRNA merupakan untaian RNA kecil (20-30 pasang basa) yang memiliki fungsi utama dalam gene silencing. Penggunaan siRNA ini memberikan efek terapi tertarget pada gen tertentu, misalnya dalam silencing gen pengekspresi protein atau molekul esensial dalam siklus hidup sel(35). Penggunaan siRNA ini terbatas akibat tantangannya dalam upaya penghantaran terbatas akibat resiko degradasi. Oleh karena itu, konstruksi siRNA dalam nanopartikel memberikan efek peningkatan stabilitas saat penghantarannya ${ }^{(36)}$.

Efektivitas konstruksi APR ini sudah dibuktikan dalam sebuah studi dengan menargetkan gen ErbB3 sebagai target spesifik pada sel kanker payudara. Penggunaan kombinasi aptamer ErbB3 dengan siRNA terpaket dalam nanopartikel memberikan efek silencing ekspresi gen target secara spesifik pada sel dengan overekspresi ErbB3. Konstruksi ini memberikan efek inhibisi pada siklus sel kanker melalui silencing pada gen CDK1 (Cyclin Dependent Kinase 1) ${ }^{(15)}$

\section{Konjugat Affibodi-Hibrid DNA}

Konjugasi melalui hibridisasi DNA memberikan stabilitas yang lebih baik dibandingkan melalui penaut (linker). Selain itu, hibridisasi DNA memberikan kelebihan lain dimana sistem ini dapat menghantarkan lebih dari satu jenis agen sitotoksik aja dalam terapi kanker payudara ${ }^{(37)}$. Konstruksi konjugat diberikan melalui penghantaran via partikel emas. Penghantaran berbasis nanopartikel emas ini memberikan berbagai kemudahan dimana sifat partikel yang inert dan dapat secara kompatibel terhadap berbagai zat biokimia(38). Salah satu aplikasi konstruksi ini telah dilakukan dalam sebuah studi dimana sistem ini dibuat untuk menghantarkan dua zat aktif sitotoksik, yakni doksorubisin dan 5-fluorodeoxyuridine. Sistem ini menggunakan affibodi $Z_{\text {hcHER2:342 }}$ sebagai ligan penarget yang memiliki affinitas tinggi terhadap HER2 ${ }^{(16)}$. 
Affibodi sendiri merupakan suatu konstruksi seperti antibodi yang sama-sama memiliki afinitas terhadap suatu protein. Berbeda dengan antibodi, affibodi tidak memiliki karakteristik imunoglobulin. Affibodi memiliki keunggulan dibanding antibodi dimana affibodi tidak terbatas pada penargetan antigen saja, namun juga dapat ditargetkan pada berbagai varian protein. Selain itu, affibodi memiliki keunggulan dalam kemudahan konstruksinya dibandingkan dengan antibodi monoklonal. Affibodi dapat dikonstruksi melalui sintesis peptida maupun melalui overekspresi pada kultur sel termodifikasi( ${ }^{(39)}$.

\section{Antibodi Biparatopik-Bispesifik}

Antibodi biparatopik-bispesifik merupakan suatu upaya dalam meningkatkan efektivitas dan selektivitas terapi antibodi monoklonal. Antibodi biparatopik memiliki definisi bahwa antibodi monoklonal tersebut memiliki dua jenis paratop berbeda ${ }^{(40)}$. Sebagai contoh dalam konstruksi antibodi biparatopik terhadap HER2 dapat digunakan paratop trastuzumab dan pertuzumab. Adapun pengertian antibodi sebagai bispesifik menunjukkan bahwa antibodi tersebut dapat mengenali dua entitas sekaligus ${ }^{(17)}$.

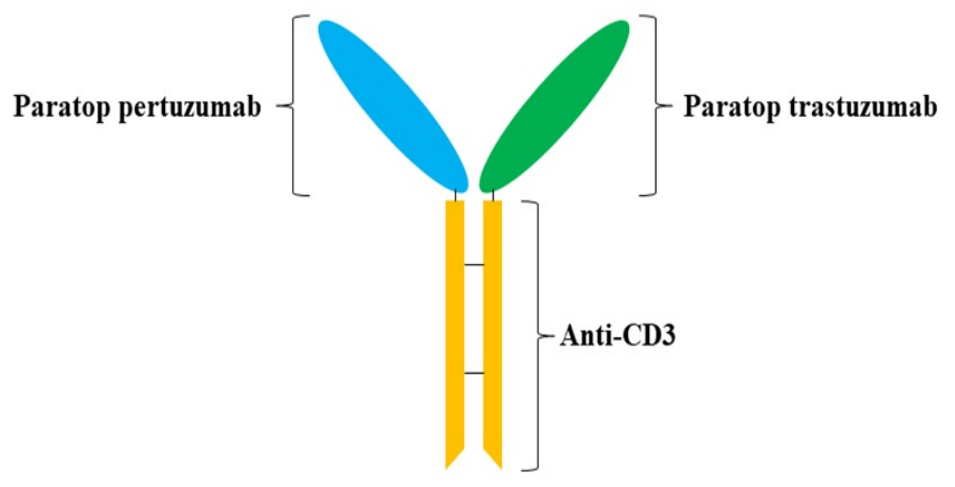

Gambar 2. Struktur konstruksi antibodi biparatopik-bispesifik menggunakan paratop trastuzumab-pertuzumab dan anti-CD3

Salah satu pengaplikasian dari sistem ini dapat dilihat pada studi konstruksi antibodi biparatopik-bispesifik terhadap HER2 dan CD3. Sebagaimana terlihat pada Gambar 2, konstruksi ini menggunakan paratop dari trastuzumab dan pertuzumab pada fragmen pengenal antigennya (Fab region), sedangkan fragment crystallizable ( $F c$ region)-nya merupakan anti-CD3 yang dapat secara spesifik mengenali CD3 pada sel $T$ sitotoksik(17,41). Melalui konstruksi ini, spesifisitas antibodi terhadap HER2 meningkat akibat dari penggunaan dari dua paratop berbeda. Sedangkan sifat bispesifik yang juga menargetkan CD3 berhasil mengundang sel T sitotoksik untuk memberikan dampak sitotoksik pada sel dengan ekspresi berlebih HER2 ${ }^{(17,42)}$. 


\section{Konjugat Sel T- Designed Ankyrin Repeat Proteins (DAR-Pins)}

Sistem ini merupakan sebuah pengembangan dari teknik imunoterapi dalam pengobatan kanker. Pada sistem ini, penghantaran tertarget dilakukan dengan melakukan dekorasi pada sel T sitotoksik yang berperan sebagai agen anti kanker oleh sebuah ligan penarget pada permukaan sel T sitotoksik. Modifikasi chimeric antigen receptor (CAR) pada sel $\mathrm{T}$ merupakan salah satu implementasi dari sistem ini. Modifikasi CAR memberikan keuntungan dimana sel $\mathrm{T}$ sitotoksik dapat diarahkan terhadap antigen yang diekspresikan berlebih dalam sel kanker melalui antibodi turunan single-chain variable fragments (scFvs) ${ }^{(43)}$. Namun demikian, penggunaan scFvs dalam sel T termodifikasi CAR belum memberikan profil spesifisitas yang diharapkan.

Salah satu pengembangan dari temuan ini adalah penggunaan designed ankyrin repeat proteins (DAR-Pins). Pada sistem ini, penghantaran tertarget dilakukan dengan melakukan dekorasi pada sel T sitotoksik yang berperan sebagai agen anti kanker oleh DAR-Pins. DAR-Pins sendiri merupakan rantai peptida berulang yang memiliki afinitas spesifik terhadap reseptor permukaan (EGFR). Adapun kelebihan dari sistem menggunakan DAR-Pins sebagai penarget ini mampu memberikan efektivitas yang lebih baik dibandingkan dengan menggunakan penarget yang pernah digunakan sebelumnya (Chimeric Antigen Receptor (CAR)). Hal ini dapat terjadi akibat DAR-Pins merupakan serangkaian protein berulang sehingga memberikan afinitas yang lebih kuat pada reseptor target.

Namun demikian, sistem ini masih menunjukkan kekurangan pada aspek stabilitas sehingga penghantarannya memerlukan media yang dapat memberikan perlindungan dalam melalui jalur penghantarannya di sistem fisiologi tubuh ${ }^{(44)}$. Sebuah studi lain menunjukkan bahwa penggunaan DAR-Pins pada sel T sitotoksik termodifikasi CAR memberikan efektivitas yang lebih besar dibandingkan dengan penggunaan sel $T$ termodifikasi CAR saja(18)

\section{Konjugat Multikomponen dalam Bentuk Dendrimer PAMAM}

Konstruksi ini memiliki kemiripan yang besar dengan konstruksi konjugat antibodi-obat. Perbedaan utama antara keduanya terletak pada linker-nya dimana dalam sistem multi komponen ini digunakan dendrimer PAMAM (poli(amidoamin)) sebagai penaut silangnya. Dendrimer PAMAM merupakan kelompok makromolekul sintetik bercabang dan mono-dispersi dengan struktur dan komposisi yang terdefinisi dengan baik ${ }^{(45)}$. Melalui penggunaan dendrimer PAMAM ini dapat memberikan muatan yang lebih besar dan heterogen dalam penghantaran obat serta memberikan profil keamanan yang lebih baik melalui pelepasan obat secara berkala(46,47). 
Studi penghantaran melalui konstruksi ini berhasil diaplikasikan pada penghantaran dosetaksel dan paklitaksel terhadap sel kanker payudara. Sistem ini menggunakan PAMAM G4 (PAMAM generasi 4) dimana jenis ini memiliki kelebihan secara struktural yang simetris sehingga memberikan profil stabilitas yang lebih baik dibandingkan generasi sebelumnya ${ }^{(19,48,49)}$. Studi ini menggunakan trastuzumab sebagai ligan penarget spesifik HER2. Konstruksi ini memberikan efektivitas yang lebih besar apabila dibandingkan dengan penghantaran secara tunggal maupun dengan dendrimer PAMAM agen sitotoksik tunggal ${ }^{(19)}$.

\section{Chimera Bivalen Aptamer-siRNA}

Konstruksi ini merupakan suatu gabungan antara aptamer (suatu antibodi asam nukleat) dan siRNA membentuk suatu chimera. Chimera sendiri memiliki artian bagi suatu entitas yang mengandung dua komponen berbeda(50). Sebuah studi memanfaat konstruksi ini dalam peningkatan terapi kanker payudara positif HER2 dan EGFR. Konstruksi dilakukan dengan menggabungkan dua aptamer HER2 (bivalen) dengan siRNA dari gen EGFR sebagaimana dapat terlihat pada Gambar 3. Konstruksi ini terbukti memberikan efektivitas yang tinggi, baik dalam induksi apoptosis pensinyalan HER2 maupun pada silencing gen EGFR ${ }^{(20)}$.

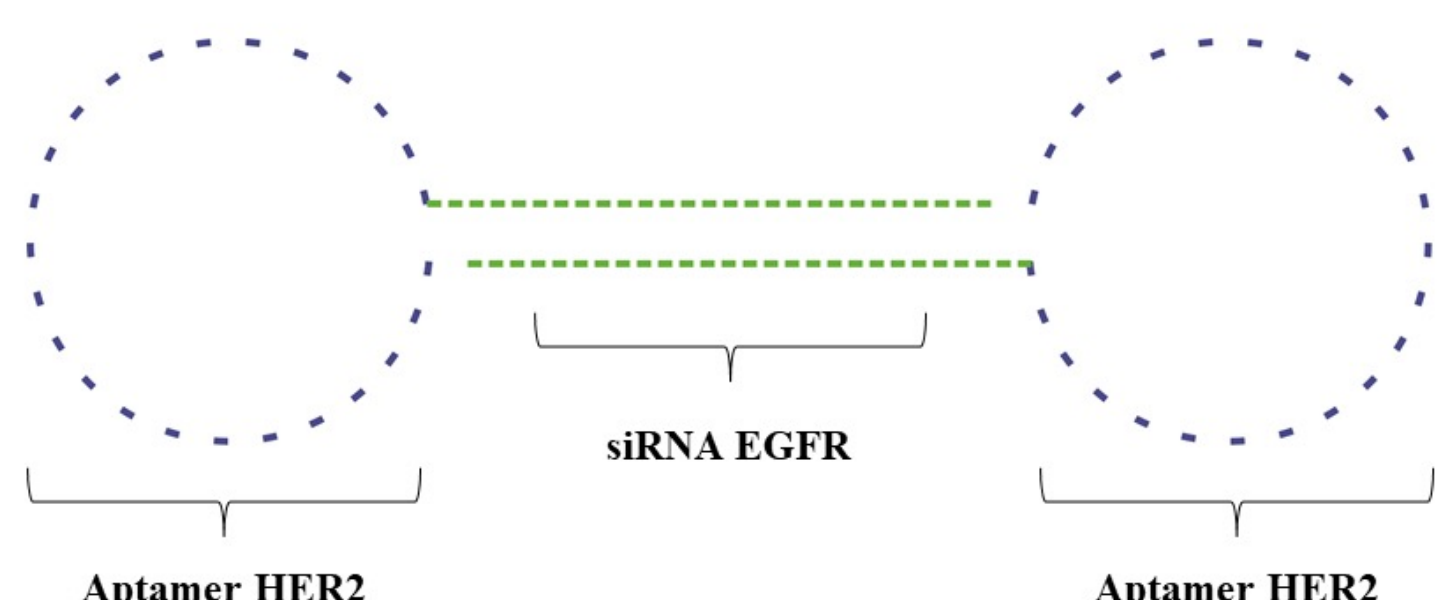

Gambar 3. Konstruksi chimera bivalen aptamer HER2 dan siRNA EGFR

\section{Kesimpulan}

Berdasarkan telaah pustaka sistematis yang telah dilakukan, dapat diketahui berbagai perkembangan sistem baru penghantaran obat tertarget EGFR pada kanker payudara. Sistem penghantaran tertarget EGFR dalam bentuk konjugat antibodi-obat (KAO) merupakan jenis sistem penghantaran yang banyak dilakukan riset pada penggunaannya untuk terapi kanker payudara. Sistem KAO ini menunjukkan prospek yang lebih baik dengan telah diperolehnya sediaan yang teregistrasi dan digunakan pada tuntunan pengobatan kanker payudara, seperti T-DM1. Sistem KAO ini memberikan kemudahan dalam pengembangannya karena sifatnya yang konvensional dengan memanfaatkan berbagai sumber daya yang telah tersedia sebelumnya. 


\section{Daftar Pustaka}

1. Akram M, lqbal M, Daniyal M, Khan AU. Awareness and current knowledge of breast cancer. Biol Res. 2017 Oct 2;50(1):33.

2. WHO. Cancer Country Profile. 2020. Available from: https://gco.iarc.fr/today/data/factsheets/populations/360-indonesia-fact-sheets.pdf

3. Moo T-A, Sanford R, Dang C, Morrow M. Overview of Breast Cancer Therapy. PET Clin. 2018 Jul;13(3):339-54

4. Nounou MI, ElAmrawy F, Ahmed N, Abdelraouf K, Goda S, Syed-Sha-Qhattal H. Breast Cancer: Conventional Diagnosis and Treatment Modalities and Recent Patents and Technologies. Breast Cancer (Auckl). 2015 Sep 27;9(Suppl 2):17-34.

5. Iqbal N, Iqbal N. Human Epidermal Growth Factor Receptor 2 (HER2) in Cancers: Overexpression and Therapeutic Implications. Mol Biol Int. 2014;1-9.

6. Masuda H, Zhang D, Bartholomeusz C, Doihara H, Hortobagyi GN, Ueno NT. Role of epidermal growth factor receptor in breast cancer. Breast Cancer Res Treat. 2012/10/17. 2012 Nov;136(2):331-45.

7. Mohan N, Jiang J, Dokmanovic M, Wu WJ. Trastuzumab-mediated cardiotoxicity: current understanding, challenges, and frontiers. Antib Ther. 2018 Aug 31;1(1):13-7.

8. Jin MH, Nam A-R, Park JE, Bang J-H, Bang Y-J, Oh D-Y. Resistance Mechanism against Trastuzumab in HER2-Positive Cancer Cells and Its Negation by Src Inhibition. Mol Cancer Ther. 2017 Jun;16(6):1145-54.

9. Iqbal J, Anwar F, Afridi S. Targeted Drug Delivery Systems and Their Therapeutic Applications in Cancer and Immune Pathological Conditions. Infect Disord Drug Targets. 2017;17(3):149-59.

10. Si Y, Xu Y, Guan J, Chen K, Kim S, Yang ES, et al. Anti-EGFR antibody-drug conjugate for triple-negative breast cancer therapy. Eng Life Sci. 2020 Oct 7;21(12):37-44.

11. Ogitani $\mathrm{Y}$, Hagihara K, Oitate $\mathrm{M}$, Naito $\mathrm{H}$, Agatsuma T. Bystander killing effect of DS8201a, a novel anti-human epidermal growth factor receptor 2 antibody-drug conjugate, in tumors with human epidermal growth factor receptor 2 heterogeneity. Cancer Sci. 2016/06/22. $2016 \mathrm{Jul} ; 107(7): 1039-46$.

12. Kumar A, Lale S V, Aji Alex MR, Choudhary V, Koul V. Folic acid and trastuzumab conjugated redox responsive random multiblock copolymeric nanocarriers for breast cancer therapy: In-vitro and in-vivo studies. Colloids Surfaces B Biointerfaces. 2017;149:369-78.

13. Ito K, Mitsunaga M, Nishimura T, Saruta M, Iwamoto T, Kobayashi $H$, et al. NearInfrared Photochemoimmunotherapy by Photoactivatable Bifunctional Antibody-Drug Conjugates Targeting Human Epidermal Growth Factor Receptor 2 Positive Cancer. Bioconjug Chem. 2017 May;28(5):1458-69.

14. Pascual T, Oliveira M, Ciruelos E, Bellet Ezquerra M, Saura C, Gavilá J, et al. SOLTI-1805 TOT-HER3 Study Concept: A Window-of-Opportunity Trial of Patritumab Deruxtecan, a HER3 Directed Antibody Drug Conjugate, in Patients With Early Breast Cancer. Front Oncol. 2021 Apr 23;11:638482.

15. Xu X, Li L, Li X, Tao D, Zhang P, Gong J. Aptamer-protamine-siRNA nanoparticles in targeted therapy of ErbB3 positive breast cancer cells. Int $\mathrm{J}$ Pharm. 2020;590:119963. 
16. Zhang $\mathrm{C}$, Zhang F, Han M, Wang X, Du J, Zhang H, et al. Co-delivery of 5fluorodeoxyuridine and doxorubicin via gold nanoparticle equipped with affibodyDNA hybrid strands for targeted synergistic chemotherapy of HER2 overexpressing breast cancer. Sci Rep. 2020 Dec 16;10(1):22015.

17. Liu J, Wu X, Lin L, Pan H, Wang Y, Li Y, et al. Bp-Bs, a Novel T-cell Engaging Bispecific Antibody with Biparatopic Her2 Binding, Has Potent Anti-tumor Activities. Mol Ther oncolytics. 2019 Apr 2;14:66-73.

18. Siegler E, Li S, Kim YJ, Wang P. Designed Ankyrin Repeat Proteins as Her2 Targeting Domains in Chimeric Antigen Receptor-Engineered T Cells. Hum Gene Ther. 2017/06/22. 2017 Sep;28(9):726-36.

19. Marcinkowska M, Stanczyk M, Janaszewska A, Sobierajska E, Chworos A, KlajnertMaculewicz B. Multicomponent Conjugates of Anticancer Drugs and Monoclonal Antibody with PAMAM Dendrimers to Increase Efficacy of HER-2 Positive Breast Cancer Therapy. Pharm Res. 2019 Sep 3;36(11):154.

20. Xue L, Maihle NJ, Yu X, Tang S-C, Liu HY. Synergistic Targeting HER2 and EGFR with Bivalent Aptamer-siRNA Chimera Efficiently Inhibits HER2-Positive Tumor Growth. Mol Pharm. 2018/10/01. 2018 Nov 5;15(11):4801-13.

21. Ponziani S, Di Vittorio G, Pitari G, Cimini AM, Ardini M, Gentile R, et al. AntibodyDrug Conjugates: The New Frontier of Chemotherapy. Int J Mol Sci. 2020 Jul 31;21(15):5510.

22. Dan N, Setua S, Kashyap VK, Khan S, Jaggi M, Yallapu MM, et al. Antibody-Drug Conjugates for Cancer Therapy: Chemistry to Clinical Implications. Pharmaceuticals (Basel). 2018 Apr 9;11(2):32.

23. Birrer MJ, Moore KN, Betella I, Bates RC. Antibody-Drug Conjugate-Based Therapeutics: State of the Science. J Natl Cancer Inst. 2019 Jun;111(6):538-49.

24. Diamantis N, Banerji U. Antibody-drug conjugates--an emerging class of cancer treatment. Br J Cancer. 2016/01/07. 2016 Feb 16;114(4):362-7.

25. Verma S, Miles D, Gianni L, Krop IE, Welslau M, Baselga J, et al. Trastuzumab emtansine for HER2-positive advanced breast cancer. N Engl J Med. 2012 Nov;367(19):1783-91.

26. Yi JH, Kim SJ, Kim WS. Brentuximab vedotin: clinical updates and practical guidance. Blood Res. 2017/12/26. 2017 Dec;52(4):243-53.

27. Kobayashi H, Choyke PL. Near-Infrared Photoimmunotherapy of Cancer. Acc Chem Res. 2019/07/23. 2019 Aug 20;52(8):2332-9.

28. Ogitani Y, Abe Y, Iguchi T, Yamaguchi J, Terauchi T, Kitamura M, et al. Wide application of a novel topoisomerase I inhibitor-based drug conjugation technology. Bioorg Med Chem Lett. 2016 Oct;26(20):5069-72.

29. Wien TN, Pike E, Wisløff T, Staff A, Smeland S, Klemp M. Cancer risk with folic acid supplements: a systematic review and meta-analysis. BMJ Open. 2012 Jan 12;2(1):e000653-e000653.

30. Bae SY, La Choi Y, Kim S, Kim M, Kim J, Jung SP, et al. HER3 status by immunohistochemistry is correlated with poor prognosis in hormone receptornegative breast cancer patients. Breast Cancer Res Treat. 2013 Jun;139(3):741-50.

31. Rimawi MF, Shetty PB, Weiss HL, Schiff R, Osborne CK, Chamness GC, et al. Epidermal growth factor receptor expression in breast cancer association with biologic phenotype and clinical outcomes. Cancer. 2010 Mar 1;116(5):1234-42. 
32. Chau CH, Steeg PS, Figg WD. Antibody-drug conjugates for cancer. Lancet (London, England). 2019 Aug;394(10200):793-804.

33. Zhang Y, Lai BS, Juhas M. Recent Advances in Aptamer Discovery and Applications. Molecules. 2019 Mar 7;24(5):941.

34. Zhou J, Rossi J. Aptamers as targeted therapeutics: current potential and challenges. Nat Rev Drug Discov. 2017;16(3):181-202.

35. Dana H, Chalbatani GM, Mahmoodzadeh H, Karimloo R, Rezaiean O, Moradzadeh A, et al. Molecular Mechanisms and Biological Functions of siRNA. Int J Biomed Sci. 2017 Jun;13(2):48-57.

36. Itani R, Al Faraj A. siRNA Conjugated Nanoparticles-A Next Generation Strategy to Treat Lung Cancer. Int J Mol Sci. 2019 Dec 3;20(23):6088.

37. de Vries JW, Zhang F, Herrmann A. Drug delivery systems based on nucleic acid nanostructures. J Control Release. 2013 Dec;172(2):467-83.

38. Kong F-Y, Zhang J-W, Li R-F, Wang Z-X, Wang W-J, Wang W. Unique Roles of Gold Nanoparticles in Drug Delivery, Targeting and Imaging Applications. Molecules. 2017 Aug 31;22(9):1445.

39. Feldwisch J, Tolmachev V. Engineering of affibody molecules for therapy and diagnostics. Methods Mol Biol. 2012;899:103-26.

40. Akiba H, Takayanagi K, Kusano-Arai O, Iwanari H, Hamakubo T, Tsumoto K. Generation of biparatopic antibody through two-step targeting of fragment antibodies on antigen using SpyTag and SpyCatcher. Biotechnol reports (Amsterdam, Netherlands). 2020 Jan 11;25:e00418-e00418

41. Yang $\mathrm{H}$, Parkhouse RME, Wileman T. Monoclonal antibodies that identify the CD3 molecules expressed specifically at the surface of porcine gammadelta-T cells. Immunology. 2005 Jun;115(2):189-96.

42. Ames E, Hallett WHD, Murphy WJ. Sensitization of human breast cancer cells to natural killer cell-mediated cytotoxicity by proteasome inhibition. Clin Exp Immunol. 2009 Mar;155(3):504-13.

43. Kulemzin S V, Kuznetsova V V, Mamonkin M, Taranin A V, Gorchakov AA. Engineering Chimeric Antigen Receptors. Acta Naturae. 2017;9(1):6-14.

44. Smithwick E, Stewart MW. Designed Ankyrin Repeat Proteins: A Look at their Evolving Use in Medicine with a Focus on the Treatment of Chorioretinal Vascular Disorders. Antiinflamm Antiallergy Agents Med Chem. 2017;16(1):33-45.

45. Abedi-Gaballu F, Dehghan G, Ghaffari M, Yekta R, Abbaspour-Ravasjani S, Baradaran B, et al. PAMAM dendrimers as efficient drug and gene delivery nanosystems for cancer therapy. Appl Mater today. 2018/05/29. 2018 Sep;12:17790.

46. Madaan K, Kumar S, Poonia N, Lather V, Pandita D. Dendrimers in drug delivery and targeting: Drug-dendrimer interactions and toxicity issues. J Pharm Bioallied Sci. 2014 Jul;6(3):139-50.

47. Chis AA, Dobrea C, Morgovan C, Arseniu AM, Rus LL, Butuca A, et al. Applications and Limitations of Dendrimers in Biomedicine. Molecules. 2020 Sep 1;25(17):3982.

48. Araújo RV de, Santos S da S, Igne Ferreira E, Giarolla J. New Advances in General Biomedical Applications of PAMAM Dendrimers. Molecules. 2018 Nov 2;23(11):2849. . 
49. Kavyani S, Amjad-Iranagh S, Modarress H. Aqueous poly(amidoamine) dendrimer G3 and G4 generations with several interior cores at pHs 5 and 7: a molecular dynamics simulation study. J Phys Chem B. 2014 Mar;118(12):3257-66

50. De Los Angeles A, Pho N, Redmond Jr DE. Generating Human Organs via Interspecies Chimera Formation: Advances and Barriers. Yale J Biol Med. 2018 Sep 21;91(3):333-42. 